Article

\title{
Design in Planning: Reintegration through Shifting Values
}

\author{
Danielle Zoe Rivera
}

Environmental Design, University of Colorado Boulder, Boulder, CO 80304, USA; E-Mail: danielle.rivera@colorado.edu

Submitted: 16 September 2020 | Accepted: 12 November 2020 | Published: 24 February 2021

\begin{abstract}
Design is increasingly entering planning beyond the subfield of urban design. At a larger scale, designers are moving into the social sciences to apply design skills at intersections with the social sciences. This article offers an overview of research and practice at the forefront of both interpreting design fields and understanding their growing importance within planning. This transcends examinations of urban design to incorporate the potential of design more broadly in planning, with particular emphasis on community development and engagement. The article does this through a case study of an existing design-based nonprofit (bcWORKSHOP) which leverages techniques across design and planning to generate new forms of community planning practice in the State of Texas. Ultimately, this case study begins to ask whether planning can fully address a number of issues (like social/racial justice and climate change) without understanding these issues from both design and planning perspectives simultaneously. It also emphasizes the importance of training planners to both envision and build alternate possible worlds, a skillset fundamental to design that could reshape planning education and practice.
\end{abstract}

\section{Keywords}

design; planning research; community-based design; interdisciplinary research; design practice

\section{Issue}

This article is part of the issue "Innovations and Development in Urban Planning Scholarship and Research" edited by Thomas W. Sanchez (Virginia Tech, USA).

(C) 2021 by the author; licensee Cogitatio (Lisbon, Portugal). This article is licensed under a Creative Commons Attribution 4.0 International License (CC BY).

\section{Introduction}

Queremos ser nosotros los que diseñemos y controlemos nuestros proyectos de vida [We, ourselves, want to be those that design and control our life projects]. (Elicura Chihuailaf, as cited in Escobar, 2017, p. 16)

Design is rapidly transforming, with profound implications for planning practice and research. Historically portrayed as a utopic endeavor (Hall, 2014; Healey, 1997, pp. 17-19; Marcuse, 2016), design has long been considered a subject to avoid in planning. However, the most urgent issues facing planning in the 21st century (like social/racial justice and climate justice) require a reorientation towards the nature of life and space, a rethinking of possible futures: This requires the skills and techniques of design. Designers have been at this point for years and already contribute significantly to examinations of social/racial justice and climate justice in planning research. Much of this recent work is driven by researchers who formerly worked within the humanities in the design professions, chiefly architecture, landscape architecture, and urban design. Taken together, this research represents a major forefront in planning, one that seeks to broaden the impacts of design on planning beyond New Urbanism or street designs to fundamentally reconceptualize planning research and its influence on real communities.

To discuss these efforts, I use the following definitions for 'planning' and 'design.' Following Van Assche, Beaunen, Duineveld, and De Jong (2012, p. 179), planning is defined as "the coordination of policy and practice affecting spatial organization." Placing academic planning alongside its peers, most are quick to label planning a social science in recognition of its historical emphasis on policy environments and sociological phenomena before concerns of space; however, a growing number of planning scholars, steeped in design fields, are questioning the premise of this orientation. In contrast, following Escobar (2017, p. 21) design is defined as "an 
ethical praxis of world-making." This orientation towards design will be explained in more detail through the literature review, but represents the shift in design described throughout the article. It should be noted that the relationship between planning and design differs substantially from country to country. Here, I focus extensively on the U.S. context, where planning and design have endured a fractured relationship.

From this, the article first offers an overview of what constitutes design and how new, expansive definitions of the field are engaging the social sciences. Second, I follow Faste and Faste (2012), who distinguish between knowledge resulting "from the 'study of design"' versus knowledge created "during the 'act of design"' (p. 2). To do so, I examine the 'study of design,' describing the methods and justice-based orientation of new studies. Subsequently, I highlight the 'act of design' through a case study of bcWORKSHOP, a Texas-based interdisciplinary design nonprofit that has received national attention for its contributions to housing design and policy. To conclude, I consider how definitions of design, within planning research, need to transform to capture the true breadth and impacts of this work within planning.

\section{Methods}

To undertake the analyses in subsequent sections, the research took inspiration from open-ended interviews with bcWORKSHOP-based designers and/or planners. In an earlier project on South Texas community organizing, conducted between 2013 and 2017, a theme emerged from six interviews and four years of participant observations of bcWORKSHOP community engagement events: Namely, that a shift in approach to design was needed to meet the needs of low-income communities of color. This was followed up with four additional interviews that asked about bcWORKSHOP's approaches to design and planning, as well as clarifying two of their projects; one which is recounted here, and another which is recounted elsewhere (Rivera, 2020). Interviews and observations underwent a two-phase analysis in Atlas.TI (one in 2017 and one in 2020) that used an analytic framework derived from a relational power perspective emphasizing objectives, obstacles, tactics, attitudes, emotions, and unspoken subtexts surrounding bcWORKSHOP's design work. A relational power perspective is crucial, as subtexts regarding the designer as a 'facilitator' as opposed to 'expert' were consistent throughout the interviews and observed communityengaged design events.

From this, larger shifts in the design professions emerged as a major subtext within bcWORKSHOP's work. The literature review below focuses on recent design scholarship that emphasizes these 'ontological' shifts, bolstered by informal discussions with several junior urban design practitioners and faculty who have not yet published on this topic, but are well-known within this area.

\section{What Is Occurring in the Design Professions? What Is Their Ontological Shift?}

While design and planning have their origins in the Neolithic times (Van Assche et al., 2012, p. 182), I begin, here, in the modern industrial era, a time period that design continues to reckon with. Industrial notions of design often privilege objects over all else, traditionally favoring technical prowess, abstract discourse, and problem-solving over social inequities (Cuff, LoukaitouSideris, Presner, Zubiaurre, \& Crisman, 2020, p. 9). This industrial orientation of design has long been criticized; in particular, Marcuse $(2016$, p. 121) referred to this phenomenon as "designer planning" whereby the output (object) becomes more important than the process. In numerous frameworks of traditional planning thought (Hall, 2014; Healey, 1997, pp. 17-19; Marcuse, 2016; Van Assche et al., 2012, p. 184), design is typically cast as a utopic endeavor, concerned more with output than with process. The often-used examples of such a design orientation are utopic modernist designers, such as Le Corbusier and Ebenezer Howard. Their formbased orientation and tabula rasa processes are used to entrench the view that planning ought to distance itself from design.

Since the 1960s, architecture, in particular, has faced such criticisms head-on. Most notably, in a 1968 meeting of the American Institute of Architects, prominent civil rights leader Whitney Young told the gathering of architects:

You are not a profession that has distinguished itself by your social and civic contributions to the cause of civil rights, and I am sure this does not come to you as any shock. You are most distinguished by your thunderous silence and your complete irrelevance. (AIA New York, 2018)

These critiques directed towards designer planning or utopic design are not incorrect; the continuing legacies of urban renewal (Jacobs, 1961; Von Hoffman, 2008) and contemporary ties between New Urbanism and processes of gentrification (Quastel, 2009, p. 699; Slater, 2009, pp. 305-306) reify these concerns. However, several designers have attempted to address these critiques, even from the onset of modernism (Sitte, 1889). Most notably, Michael Sorkin (2001, p. 4) boldly stated, "decades of well-rehearsed critiques of the Master Plan have resulted in a baby-with-the-bathwaterism, in a reticence of vision." As an expression of faith in the potential for design to remake itself, Sorkin's work has inspired and continues to inspire an entire generation of new designers.

Silence on social and, later, environmental concerns was addressed in small ways with object-centered design responses but transformed throughout the 2000s and 2010s. With the Occupy Wall Street movement, and at a time when design jobs were scarce, young designers 
noted parallels to their professions. A common refrain was that design only assisted a privileged $10 \%$ of the population, avoiding the $90 \%$ that could not afford exorbitant fees (Architecture for Humanity, 2006; Cooper Hewitt, 2007). Early notions of pro bono architecture, humanitarian design, and design for the $90 \%$ all attempted to expand the reach of design; however, these attempts largely failed to reorient the design profession due to their continued emphasis on objects, through 'interventions' and entrepreneurship, rather than on an epistemological reorientation of the disciplines' goals. In response, there has been a call for more reflexive practices of community-based design (Francis, 2005, p. 18).

This constitutes a profound movement away from aging industrial notions of design to a re-evaluation of its connection to life and world (Hou, Francis, \& Brightbill, 2005). Arturo Escobar (2017), in studying the shifts in design through Designs for the Pluriverse: Radical Independence, Autonomy, and the Making of Worlds, identifies this new wave of design:

[There is a] significant reorientation of design from the functionalist, rationalistic, and industrial traditions from which it emerged, and within which it still functions with ease, toward a type of rationality and set of practices attuned to the relational dimensions of life. (Escobar, 2017, p. X)

However, due to this reorientation, there is a growing schism in design, with some emphasizing speculative and capitalist modes of design, while others emphasize avoiding the "creation through destruction" associated with capitalist modes (Escobar, 2017, p. 11). Reorientations of design, then, involve an ontological shift that reconceptualizes design in terms of its connection to real communities. As Cruz and Forman (2015) note:

The most relevant new urban practices and projects promoting social and economic inclusion are emerging not from sites of economic power but from sites of scarcity and zones of conflict, where citizens themselves, pressed by socioeconomic injustice, are pushed to imagine alternative possibilities. It is from this sense of urgency that a new political agenda is emerging, one in which urban design and architecture will take a more critical stance against the discriminatory policies and economics that produced inequality and marginalization. At this moment, it is not buildings but the fundamental reorganization of social and economic relations that is the essential [sic] for the expansion of democracy and justice in the city. (Cruz \& Forman, 2015, para. 4)

From this, and beyond classifications of disciplines, design is being newly reimagined as "a culture and a practice concerning how things ought to be in order to attain desired functions and meanings" (Manzini, 2015, p. 53). In examining what 'ought to be,' the growing onto- logical shift in design leverages the skillset of designers to reimagine and institute a more just future, or "to consider a situation, imagine a better situation, and act to create that improved situation" (Vial, 2019, p. XI). As such, design becomes less concerned with industrialmodernist conceptions of design as objects and more concerned with design as envisioning alternative worlds and futures. As Bryan Lee Jr. states:

To design is to have an unyielding faith in the potential for a just society. It is an act of individual and collective hope requiring not only an awareness of true inequity, but a compulsion to speak out against it in its many forms. Design speaks to the potential for equitable spaces and attempts to visually and physically represent our collective aspirations for the future. (Bryan Lee Jr., as cited in Wilson, 2018, p. 169)

Lee's notion of 'collective aspirations' is key, as new ontologies of design purposefully de-center the designer as a solitary genius, instead framing the designer as a facilitator of discussions about an aspirational future. This involves pushing past the object-oriented design ideas of a single future and instead focuses on "embracing paradox" (Mau, Leonard, \& Institute Without Boundaries, 2004, pp. 18-19) and interpolating between multiple notions of the future (Escobar, 2017, p. 3).

From this perspective, design is not simply about problem solving, but is instead about collectively envisioning the future. As Escobar describes:

[As this new ontological orientation of design] moves out of the studio and the classic design professions....and into all domains of knowledge and applications, the distinction between expert and user/client breaks down. Not only does everyone come to be seen as a designer of sorts, but the argument for a shift to people-centered (and, to a lesser extent, earth-centered) design is more readily acknowledged. Designing people and the environment back into situations also means displacing the focus from stuff to humans, their experiences and contexts. [It means moving] from mindless development to design mindfulness, from technological fixes to more design, from object-centered design to human-centered design, and from 'dumb design' to 'just design.' (Escobar, 2017, p. 34)

Design research and practice in its newer orientations is concerned with the study of "how the world gets put back together" (Mattern, 2018, para. 2). Specifically, as Susmita Rishi (personal communication, 2020) frames it, we must now "design with, not for."

\section{The 'Designer-Turned-Planner' in Research}

The ontological shift in design, whether consciously or not, is impacting research throughout the social sciences 
and humanities as designers merge training in the nature of space with critical studies from humanities and the humanistic social sciences. Specifically, changes in design perspectives are increasingly influencing planning scholarship, and even its practices and orientations towards the 'future' that planning aspires to affect. The usual limitation within planning, however, is that the designers only use their skills within a particular subset of the field where design skills are necessary. Mapping, street-level infrastructure, land use, and more object-oriented subfields of planning are considered the traditional domains of the 'designer-turned-planner'; however, designers are increasingly leveraging shifts in design ontologies to push the field to more radically reconsider notions of the future. I review three forms of design-based research following Faste and Faste (2012, p. 3): 1) empirically oriented research examining the nature of the world through direct, qualitative observations; 2) practice oriented research focusing on informed design form, craft, and prototyping; and 3) speculatively oriented research posing theoretical and cultural questions.

To examine these forms, I cover two interrelated topics introduced by bcWORKSHOP as critical to the shifts in design perspective: social justice and uneven environmental risks. This emphasizes two key areas where designers-turned-planners are transforming design: planning for social and racial justice, and planning for climate change and climate justice. These foci have been transformed by the new ontological orientation of design as the notion of designer as a facilitator, rather than an expert, has profound implications for how we understand the issues that generate social, racial, and/or climate injustices in the physical space of communities.

\subsection{Design in Planning for Social and Racial Justice}

We should advocate for an outreaching, inclusive architecture, that responds forthrightly to the social, ecological, and cultural issues of this time, and for our grandchildren's future. (Bond, 2008)

The most impactful shift in design can be seen through the movements for social and racial justice. As Bryan Lee Jr., Architect and Director of Colloqate Design explains, meaningful movement towards racial and social justice necessitates an orientation away from end results and an emphasis on a new design process (as cited in Pedersen, 2020). This reorientation is meant to solidify relational forms of justice in the design process, repairing inequitable power relationships that disallowed disenfranchised communities from participating in design processes directly affecting them (Hou, 2018, p. 15; Lee, 2020, paras. 3-4). This involves an act of humility by understanding one's role as a designer within a given context (Moore, 2015). According to Jeff Hou (2018, pp. 10-11), those engaged in these forms of community engagement at intersections of design and planning do not often remain in research, but actively engage in col- laborations with communities, generating key insights for design and planning research in their process.

To illustrate this point, Bryan Lee Jr. explicitly asks what it means and looks like to design spaces that do not center whiteness (Pedersen, 2020). Based in New Orleans, Louisiana, Colloqate Design works with communities to expose and address inequities in the built environment. Paper Monuments, one of their recent projects, uses public space as an artist's canvas to highlight obscured and forgotten histories underpinning inequity across historically Black neighborhoods in New Orleans. They call this form of designing "design justice" or action to "dismantle the privilege and power structures that use architecture as a tool of oppression and [see] it as an opportunity to envision radically just spaces centered on the liberation of disinherited communities" (Lee, 2020, para. 3). In this manner, striving for social and racial justice transcends design to critically include policies and teachings (Pedersen, 2020, para. 15). As such, design justice is a growing area of research and practice that emphasizes the need to move beyond well-intentioned projects to view design as a liberatory process (Costanza-Chock, 2020, pp. 6-7). The major contribution of design justice is the visioning of a more just future, one in which design is no longer seen as a practice of the elite, as Lee states: "We must act swiftly and sustain our efforts to reconstitute our profession as a coconspirator to justice" (Lee, 2020, para. 28).

Design justice is greatly influencing the practices of community engagement and community development. Design justice derives extensively from community development practices and research, early on adopting ideas like participatory action research into community design processes (Hou et al., 2005). However, now it seems that design justice approaches are reinforming community development practices, particularly through the addition of design tools and perspectives. To illustrate, Lee notes that design justice necessarily involves two practices (Pedersen, 2020, para. 23). First is ground setting or defining the conditions within a community and valued spaces, not from the perspectives of the city, but from the perspectives of the community. Second is baselining or assembling the collective memory or insurgent historiography of the community. Similar approaches are being undertaken in design research and pedagogy; the most notable of these is UCLA Urban Humanities, which merges design, humanities, and urban studies to address the most pressing issues facing cities (Cuff et al., 2020). Urban Humanities leverages three core componentsthick mapping, spatial ethnography, and filmic sensingto more clearly understand the potential future implications of interdisciplinary research in urban studies (Cuff et al., 2020, p. 28)

These practices and research display the community and participatory approaches needed to meaningfully work with communities to not just envision change, but also enact it. A notable example of this is Leonie Sandercock's work with First Nations. As a trained 
screenwriter, Sandercock has used film to reconceptualize participation and collaboration in planning practices. Her films, with Giovanni Attili, include Finding Our Way (2010) and Where Strangers Become Neighbors (2007). Sandercock and Attili (2014) highlight how the process of creating a film can form a novel basis for undertaking participatory action research and, even, reaching towards the decolonization of the planning process. Here, consensus is not the aim; instead, the aim is to create processes that envision an entirely different set of possible futures with liberation at their bases. Barbara Wilson Brown describes similar processes, stating: "Consensus is not the goal; designing for equitable, systemic change in vulnerable communities involves fusing the local knowledge of residents with the technical knowledge of professionals in small, nimble, public projects" (Wilson, 2018, p. 2).

These works are transforming community-led practices for social and racial justice. They point to goals like abolition and decolonization, noting that such goals are unachievable without a radical reconception of the relationship between policy and design or social scientific theories and reified space.

\subsection{Design in Planning for Climate Change and Climate Justice}

Design solutions for sustainability, with an eye towards addressing the contributions of the building industry to climate change, have historically focused primarily on the buildings and landscapes as objects. This focus on building forms and technologies placed the onus for change on client-based decisions and consumption patterns. Larger-scale urban design initiatives have been similarly critiqued for their inability to enact the broader scales of change needed to truly institute mitigation and adaptation for all (Anguelovski, Irazábal-Zurita, \& Connolly, 2019; Shi, 2020), as Fry notes:

Gestural egocentric architectural statements and master planning fictions measured against the scale of imperative [climate change and generalized unsettlement] are not merely misplaced, they are crimes against the future. (Fry, 2015, p. 48)

As such, designers are taking the helm in defining new relationships between underrepresented communities and climate change. This body of academic and professional work leverages the insights from design innovations on issues of social and racial justice, extending discourses on community-based design, to encompass climate futures. These works contain critiques of environmental and land use planning relative to environmental and climate justice (Steiner, 2014; Steiner, Simmons, Gallagher, Ranganathan, \& Robertson, 2013). Notable is Sarah Dooling's concept of 'ecological gentrification' or "the implementation of an environmental planning agenda related to public green spaces that leads to the displacement or exclusion of the most economically vul- nerable [referring to the homeless] while espousing an environmental ethic" (Dooling, 2009, p. 630). Specifically, Dooling critiques visions for greenspaces which do not critically examine how these spaces are used. In her Seattle-based case study examining homelessness, an uncritical view of greenspace leads to the displacement of the homeless from public spaces. Her concept of ecological gentrification has since informed countless studies and opened a new area of study on gentrification's intimate relationship with sustainability and 'greening' strategies in planning (Alkon \& Cadji, 2020; Anguelovski, Connolly, et al., 2019; Rigolon \& Németh, 2019; Sbicca, 2019).

In this way, designers continue to highlight 'hidden' infrastructures, taken as givens, which harm the environment and perpetuate harmful forms of design (Mau et al., 2004). DesignEarth, a design firm founded by architects Rania Ghosn and El Hadi Jazairy, explores fictive futures of post-oil through storytelling and visual representation (Ghosn \& Jazairy, 2020). Their work offers, at once, research-driven inquiries into physical infrastructures and visions of a potential sustainable future. Similarly working in this space, Teddy Cruz and Fonna Forman examine how the U.S./Mexico border affects the physical space and infrastructures of the San Diego/Tijuana region (Cruz, 2007; Cruz \& Forman, 2018). Their research and practice interrogating infrastructural landscapes in this international region have profound implications for how transnational environmental systems and policy are understood.

Most notable in this area, however, are the designers reflecting and building upon not just infrastructure, but also climate change policies like the Green New Deal, a series of proposed resolutions to address climate change in the U.S. (Recognizing the Duty of the Federal Government to Create a Green New Deal, 2019). While many view the Green New Deal as a series of proposed policies, a number of designers are viewing the document as a provocation for design to rethink its goals and processes, and to push the ideas within the Green New Deal (Fleming, 2019; Goh, 2020). Notably, Reinhold Martin has pointed to the uneven development from the New Deal, calling for a vision of the Green New Deal that is more overtly equitable in its orientations (Martin, 2020). These inquiries underpinned the Superstudio, a pedagogical collaboration from 2020 to 2021 across design studios nationwide to interrogate the potential spatial implications and lessons from the Green New Deal, sponsored by the University of Pennsylvania's McHarg Center and the Landscape Architecture Foundation. These teaching and professional opportunities leverage the ontological shifts in design, not just in the service of social and racial justice goals, but also for a radical reconceptualization of a future contending with climate change.

These works exemplify the current ontological shift in design and its potential implications for environmental planning. Without fluid and radical visioning for the 
future under climate change, the physical and policybased issues we face will not be fully addressed. Design tools that permit the development and implementation of alternative futures, with creativity, are sorely needed.

\section{The "Designer-Turned-Planner" in Action: bcWORKSHOP and RAPIDO}

To examine the broader implications of the work above, I present the case of bcWORKSHOP, a design and planning nonprofit founded by Brent Brown in 2005 in Dallas, Texas, that eventually expanded to satellite offices in Houston, Texas; Washington, DC; and Brownsville, Texas. BcWORKSHOP's practice, writ-large, merges architecture, landscape architecture, preservation, and planning in service of low-income communities of color. Their mission is "to improve the livability and viability of communities through the practice of thoughtful design and making" (bcWORKSHOP, 2020). To accomplish this, they follow a collaborative design approach that leverages community development and engagement techniques throughout the design process.

The case presented here focuses solely on bcWORKSHOP's Brownsville, Texas office. Founded in 2012, bcWORKSHOP's Brownsville office was created to establish their presence in the Río Grande Valley (Valley), one of the poorest regions in Texas and the U.S. (MacLaggan, 2013). Their main goal for this new office was to work within the colonias, impoverished communities along the U.S./Mexico border that lack basic utilities and adequate housing. BcWORKSHOP's work in the Valley began with a focus on housing design, which, over time, transformed with the introduction of the Ford Foundation in 2015 and its creation of a regional network of nonprofits and grassroots organizations. To examine this transformation, I first introduce and evaluate the history behind bcWORKSHOP's Brownsville office and the founding of the sustainABLEhouse initiative. Second, I examine the transformation of sustainABLEhouse into the RAPIDO project, which brought national attention to bcWORKSHOP-Brownsville.

\subsection{Establishing the sustainABLEhouse Initiative}

Immediately upon opening the Brownsville office in 2012, bcWORKSHOP began working with the Community Development Corporation of Brownsville (CDCB), a major affordable housing provider in the Valley. BcWORKSHOP's objective in working with the CDCB was to re-envision housing designs for the CDCB's 'Colonia Program,' funded by U.S. Department of Housing and Urban Development (HUD) HOME funds. The current program was based upon a self-help model of affordable housing delivery, popular across South Texas since the 1980s (Ward, 1999). Self-help housing, here, refers to 'sweat equity' homes, whereby households actively participate in the (re)construction of their own homes. The CDCB sought to address an issue with their self- help housing designs: namely, that they all relied on the same design elements and plans. While their standard, universal design reduced costs, it ultimately led to 'cookie-cutter' neighborhoods, as a bcWORKSHOP designer recalled:

You'd drive [into the community and] almost a quarter of the houses, out of the 864 houses, it's the same house, just a different color. They [CDCB] said: "You know, we're getting these families new homes-durable, efficient homes-but we're changing this neighborhood. We're making it cookie cutter and that's not what we're about." (bcWORKSHOP Designer 1, interview, 2014)

Furthermore, the CDCB wished to reduce the number of self-help homes, allowing residents to participate in the design of their new homes, but not forcing them to construct them (bcWORKSHOP Designer 3, interview, 2015; CDCB Employee 1, interview, 2014). From this, the designers and planners at bcWORKSHOP began a standard humanitarian design process of redesigning the self-help homes for the CDCB. They began with more traditional methods of engagement in the redesign process to help households envision the redesign of the homes, such as holding community focus groups, defining spaces abstractly with colored blocks, and reviewing photographs.

By 2013, these efforts were adapted into the sustainABLEhouse initiative. SustainABLEhouse uses structural insulated panels (SIPs) to establish a modular base for the CDCB's homes. SIPs are framed wall segments that are prefabricated and pre-insulated with integrated utilities. SIPs rely on a system of 4 -feet by 8 -feet panels (standard dimensions for construction materials) that not only reduce material costs, but also allow for freer construction in a 4-feet by 4 -feet grid (Figure 1). In the case at hand, this allowed affordable housing designs to be more freely configured to meet each household's specific needs (Figure 1).

Given the immense flexibility provided by SIPs, bcWORKSHOP needed to develop a new process for designing these homes. As the former designs were unable to change beyond color or material finishes, the CDCB did not have an extensive process for co-designing homes with households. To address this, bcWORKSHOP developed la tarea (the homework). La tarea is a bilingual (Spanish and English language) pamphlet containing a series of questions, prompts, diagrams, and maps to establish existing issues on lots and each family's housing desires. Households could sit with the bcWORKSHOP designers and determine the parameters for their home. Over time, bcWORKSHOP developed over one hundred distinct house plans from la tarea and the SIP panel system (bcWORKSHOP Designer 2, interview, 2014). In conceptualizing la tarea, the designers wished for households to take ownership of the design and see themselves in the process; however, that required 


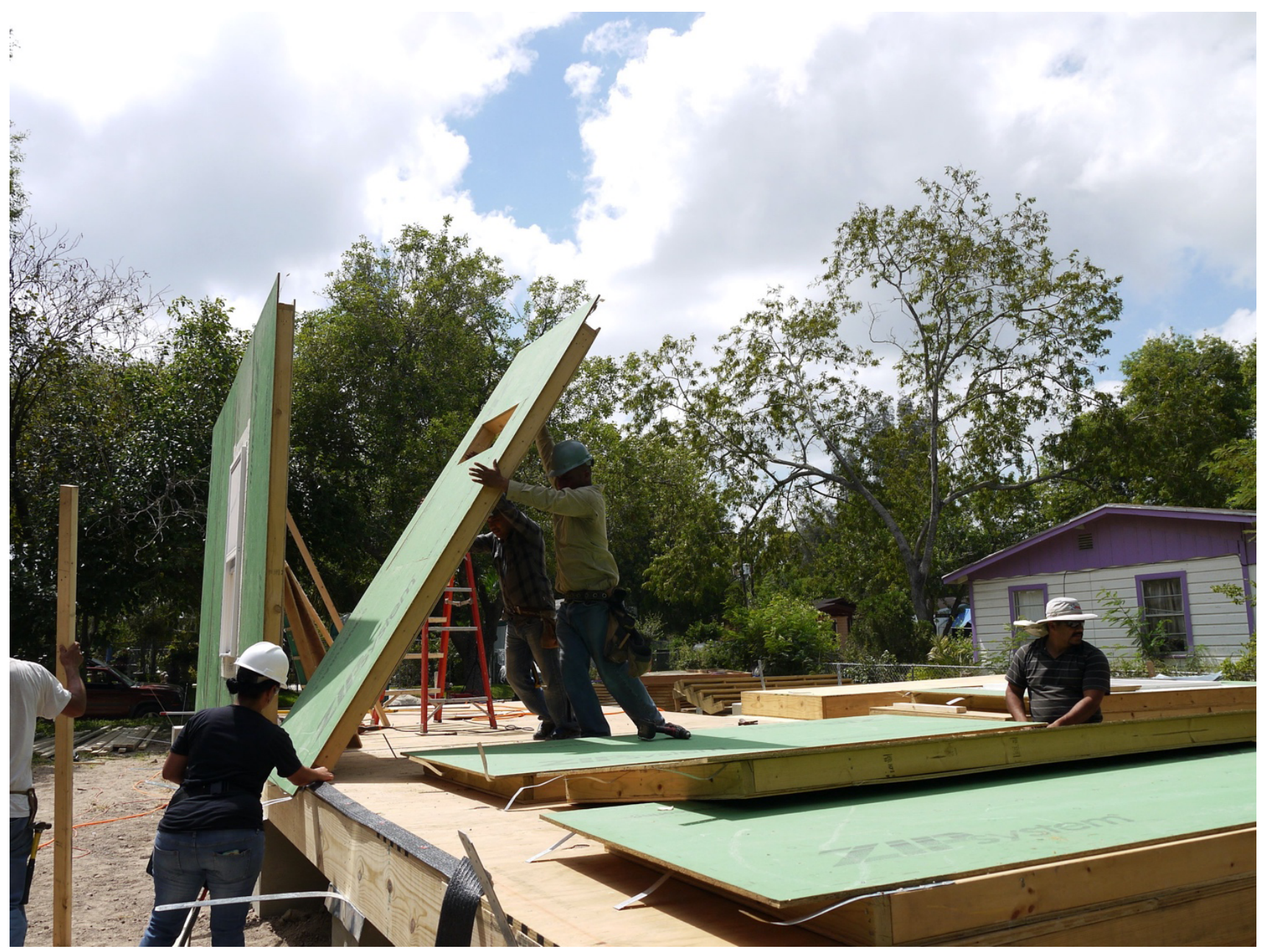

Figure 1. Photograph showing the installation of SIPs in the core of a RAPIDO prototype home. Source: bcWORKSHOP (2016).

assisting the household in understanding the multitude of design decisions involved in a design process, as one bcWORKSHOP designer stated:

When you think about designing a home with somebody who's never thought about home design, really, how do you get people thinking: "I need to make thoughtful decisions." It's what are the simple questions we can ask somebody that really gets people thinking about: How do I want the space outside my house to work? How do I want to walk into my house and what do I want to see? Or, I walk out of my house, what do I want to see? Or, when I'm sleeping, I don't want this beside my bedroom door. So, people started thinking about that so it's not just: "Hey, design your own home." (bcWORKSHOP Designer 2, interview, 2015)

The ontologies underpinning the sustainABLEhouse initiative display a shift from a modernist-industrial focus to a justice-oriented perspective that asks: Why can't low-income households design their homes without the burden of constructing it? SIPs introduced an alternative to traditional stick frame construction that minimizes material costs and also introduces flexibility into home design. However, the true ontological shift emerged from the pairing of structural freedom with design freedom. La tarea was a method for quickly establishing the household's site and programmatic expertise, while reinforcing the designer's role as a facilitator in the process. With this reconceptualization of the design process, the $\mathrm{CDCB}$ and bcWORKSHOP were able to move deftly to design and build custom houses and diversify the housing across the Valley's colonias. The additional benefit of sustainABLEhouse is that these homes adapted more to the regional culture they inhabited. In this case, the Valley residents emphasized space for extended families and the need for outdoor spaces for family gatherings. Unlike many other affordable housing programs, sustainABLEhouse could adapt to these local needs.

\subsection{The Development of RAPIDO}

As bcWORKSHOP's Brownsville office further established its presence in the Valley, it began collaborations with the Valley's many colonia-based groups, namely LUPE and 
ARISE, two of the largest grassroots organizations in the region. In 2015, this partnership was bolstered by a threeyear Ford Foundation grant that led to several projects focused on urban infrastructure (Rivera, 2020). From this, bcWORKSHOP learned of a persistent issue in the colonias, which was also evidenced in their tareas: The Valley's colonias suffer from inadequate drainage and are highly susceptible to flooding. This issue became evident during Hurricane Dolly, which made landfall in the region in 2008. Many colonia-based households reported standing water in their communities nearly 180 days after the storm (Proyecto Azteca Employee 1, interview, 2014). These issues were worsened by poorly executed postdisaster housing reconstruction; namely, the Federal Emergency Management Agency (FEMA) failed to sufficiently support reconstruction in the region's colonias by denying them reconstruction funds on a massive scale, leading to a nearly 10 -year-long lawsuit lead by LUPE (Rivera, Jenkins, \& Randolph, 2019). Hearing these concerns from the community, bcWORKSHOP explored the idea of transforming the sustainABLEhouse initiative, with its flexible SIP design, to provide rapidly-deployed post-disaster homes.

The fundamental goal, bcWORKSHOP recognized, was to reduce the time between disaster and housing reconstruction. Working with the Texas Housers, a notable Texas-based housing advocacy organization, bcWORKSHOP identified incongruities between FEMA and HUD's funding for post-disaster housing reconstruction, which created a slow and confusing recovery process for low-income households. As the problem stands, FEMA funds may be used for immediate housing recovery needs, but cannot be mixed with HUD's funding, which focuses on long-term housing recovery. BcWORKSHOP sought to address this shortcoming, which required not only policy changes, but also changes to post-disaster housing designs.
From this, the RAPIDO initiative was born. RAPIDO took the sustainABLEhouse model and recontextualized it as a housing program for on-site, post-disaster housing. The benefit is rapid deployment and construction times-much faster than current FEMA trailers (Henneberger, 2019)-and no owner-occupied displacement, as families reside in improved housing on their lots. Due to the 4-feet by 8-feet modularity of SIPs, the panels are easily delivered via standard pick-up trucks (never in short supply in Texas) in one to two trips. The initial SIPs deployed by RAPIDO include all the core elements of a functioning home: living space, kitchen, and bathroom. This immediate relief housing was called the 'core.' The core was carefully designed to meet FEMA standards and to take the place of a FEMA trailer or tent. From this core, households could expand their homes with more SIPs or with traditional stick-frame construction as funds from HUD CDBG-DR grants or elsewhere permitted. The benefit of the SIP core construction is that panels can be easily removed to become doorways or passages into home additions. Figure 2 shows how RAPIDO homes can expand over time.

To test the concept, bcWORKSHOP built twenty fully operational RAPIDO homes in the Brownsville, Texas area as a pilot project (see Figure 3 ). The cores of these prototypes were assembled and deployed to the site, as expected in a post-disaster situation. Then, bcWORKSHOP designers worked with each of the twenty households to design a unique extension to the core that served each family's needs. The RAPIDO program, and its successful pilot projects, earned bcWORKSHOP a number of accolades, notably the South by Southwest Eco Place Design Award in 2015 and a Design Corps Seed Award in 2016.

In September 2016, the City of Brownsville became the first local government to accept RAPIDO as a postdisaster housing reconstruction model. This has set into

\section{1 temporary unit}

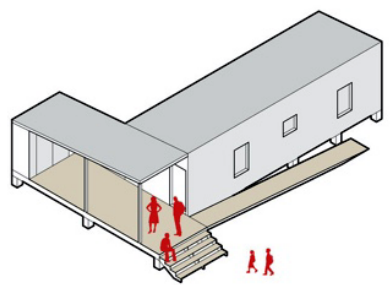

FAMILY LIVES IN THE CORE

Families receive a standardized "CORE" home that contains essential living facilities, families will reside in the CORE during four months until the eligibility
2 custom expansion

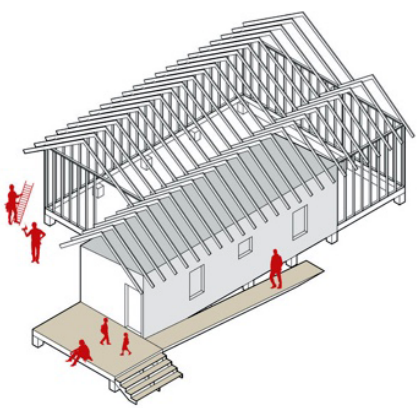

CORE IS EXPANDED TO FIT FAMILY'S NEEDS

When time and resources are available the CORE gets expanded into a permanent home. Families participate in a one-on-one design consultation to choose floorplans and home designs that can meet their neod
3 permanent home

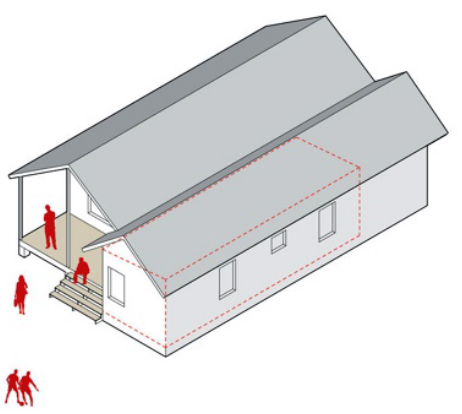

FAMILY ENJOYS HOME

The temp-to-perm approach together with the engaged design process results in home designs that increase the pride and ownership feeling. This process increases the variety families will be better prepared for the next disaster event.

Figure 2. Rendering of the deployment phases of a RAPIDO home. Source: bcWORKSHOP (2016). 


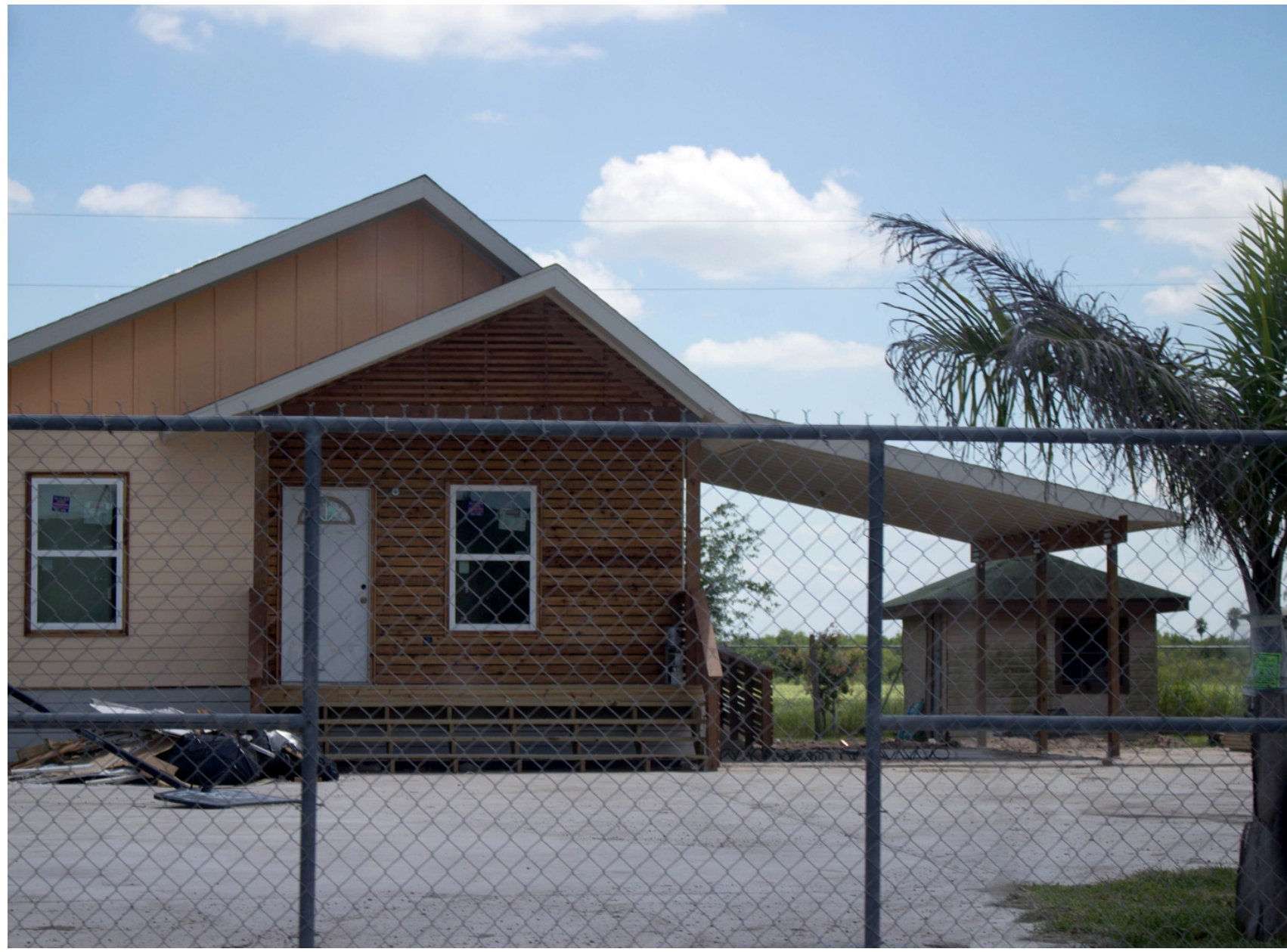

Figure 3. Nearly completed RAPIDO prototype home, designed using a sustainABLEhouse model, under construction in a colonia north of Weslaco, Texas. Source: Author (2015).

motion the adoption of RAPIDO as not just a design proposal, but, as a bcWORKSHOP designer states, disaster preparedness:

This is not only a disaster response model, but it's a disaster preparedness model, because what we did with these twenty houses is show that this isn't hard. The same process that we use for designing a custom-built house, you can do with this program and it didn't take that much time. It had to be done. (bcWORKSHOP Designer 2, interview, 2015)

True to the statement above, bcWORKSHOP did not end with the proof of concept, but worked with the Texas Housers to transform post-disaster housing policies in Texas. In 2019, after six years of concerted effort, RAPIDO was passed in the Texas legislature and signed by Governor Greg Abbott (Henneberger, 2019). The program and its technical plans (CDCB \& bcWORKSHOP, 2015) are now available to Texan coastal communities as a disaster preparedness and recovery model. Currently, Texas Housers and bcWORKSHOP hope to expand the adoption of RAPIDO to the federal level to resolve the conflicts between FEMA and HUD post-disaster fund- ing more broadly. In the meantime, bcWORKSHOP has begun constructing RAPIDO homes across Houston in the wake of Hurricane Harvey in 2017 to encourage the program's adoption in the city.

RAPIDO highlights the need to integrate planning and design, in this case to envision more equitable post-disaster housing reconstruction policy and design. To transform the recovery experience for low-income households, changes were needed to both the physical design and planning process for post-disaster housing, and these changes needed to occur in tandem. At once conducting policy analyses pointing out the shortcomings of reconstruction funding and designing contextrelevant housing, bcWORKSHOP was able to envision and enact a new future for post-disaster housing. The power of the ontological shift is that this is not a utopic vision or object-oriented design, but instead merges justice-based world-making with key planning and policy frameworks.

\section{Conclusions}

Design is an inherently spatial way of thinking about the world, and about the multiplicity of potential worlds that could exist (Escobar, 2017, pp. 15-16). As such, space 
becomes the means and methods through which designers think and act, a fundamentally different approach to the world than seen in other disciplines. In the social sciences, despite the "spatial turn" in the early 21st century (Withers, 2009), space remains secondarily or even tertiarily important and is more often considered metaphorically within a larger policy or sociological context. However, design conceptions of space extend beyond geographic information systems and nonrepresentational metaphors to encompass envisioning a multiplicity of worlds. While design, and its predilection for working in reified space, once remained in a distant corner of academia, new pathways for designers to fuse their practices and perspectives with social sciences and humanities are emerging.

This is having profound implications for planning research, particularly in its relationship to environmental concerns and in its ability to achieve more just impacts in low-income communities of color. Designers enter planning, increasingly, not just to improve geographic information systems-based research or improve street-level infrastructure, but to engage in planning because there is a need to address serious concerns, like social and racial justice and climate change, with reconceptualizations of what is possible for communities from simultaneous views of world-making and governance. These issues cannot be substantively addressed through policy or design alone, but require both to truly be successful. However, planning research has not yet fully recognized the transformations and ontological shift occurring in design. The assumption that design remains inherently objectoriented is, increasingly, incorrect. A major, untapped area of planning research, reflecting trends in designoriented research in geography and anthropology, is to re-engage with designers-turned-planners to transform what is possible in planning research and practice.

The case of bcWORKSHOP's RAPIDO and sustainABLEhouse programs illustrates the importance of engaging new conceptions of design as part of a planning strategy. Without an understanding of the design constraints posed by existing housing designs, the collaborative nature of the design process and the two-phase construction of these homes would not have been possible. It was this reconceptualization of housing design and its implications for post-disaster housing reconstruction policies that made RAPIDO so impactful.

Ultimately, the simultaneous viewing of problems from design, humanities, and social science perspectives is what is needed to envision multiple and different worlds: past, future, and current. Existing spatial patterns and policy frameworks cannot fully and satisfactorily address issues like climate change and anti-Blackness. Instead, frameworks like abolition, decolonization, mitigation, and adaptation all require new policy approaches, but also new modes of understanding and transforming real, reified space. This is the true wheelhouse of the designer.

\section{Acknowledgments}

Thank you to the reviewers for their insightful comments, which greatly strengthened the final version of the article.

\section{Conflict of Interests}

The authors declare no conflict of interests.

\section{References}

AIA New York. (2018). Historical context: Whitney M. Young, Jr.-Speech. AlA New York. Retrieved from https://www.aiany.org/membership/specialprojects/article/next-gen-arch-equity-diversityand-inclusion-initiative/whitney-youngs-speech

Alkon, A. H., \& Cadji, J. (2020). Sowing seeds of displacement: Gentrification and food justice in Oakland, CA. International Journal of Urban and Regional Research, 44(1), 108-123.

Anguelovski, I., Connolly, J. J. T., Pearsall, H., Shokry, G., Checker, M., Maantay, J., . . . Roberts, J. T. (2019). Why green "climate gentrification" threatens poor and vulnerable populations. Proceedings of the National Academy of Sciences of the United States of America, 116(52), 26139-26143.

Anguelovski, I., Irazábal-Zurita, C., \& Connolly, J. J. T. (2019). Grabbed urban landscapes: Socio-spatial tensions in green infrastructure planning in Medellín. International Journal of Urban and Regional Research, 43(1), 133-156.

Architecture for Humanity. (2006). Design like you give a damn: Architectural responses to humanitarian crises. Melbourne: Metropolis Books.

Attili, G. (Director), \& Sandercock, L. (Director). (2007). Where strangers become neighbours [Motion Picture]. Montreal: National Film Board of Canada.

Attili, G. (Director), \& Sandercock, L. (Director). (2010). Finding our way [Motion picture]. Vancouver: Moving Images.

bcWORKSHOP. (2020). Homepage. bcWORKSHOP. Retrieved from https://www.bcworkshop.org

Bond, M. J., Jr. (2008). Award address for New York chapter of AIA. New York, NY: New York Chapter of the AIA.

Community Development Corporation of Brownsville, \& bcWORKSHOP. (2015). Policy recommendations: Rapid disaster recovery housing program. Rapido Recovery. Retrieved from http://www.rapido recovery.org/technical-guides

Cooper Hewitt. (2007). Design for the other 90\%. Cooper Hewitt. Retrieved from https://www.cooperhewitt. org/2011/04/22/cooper-hewitt-design-for-theother-90

Costanza-Chock, S. (2020). Design justice: Communityled practices to build the worlds we need. Boston, MA: MIT Press. 
Cruz, T. (2007). From the global border to the border neighborhood. In G. Agamben (Ed.), Arxipèlag d'excepcions: Sobiranies de l'extraterritorialitat [Archipelagos of exception: Sovereignties of extraterritoriality] (pp. 117-144). Barcelona: CCCB.

Cruz, T., \& Forman, F. (2015, October 23). Public imagination, citizenship and an urgent call for justice. The Nature of Cities. Retrieved from https://www. thenatureofcities.com/2015/10/23/publicimagination-citizenship-and-an-urgent-call-forjustice

Cruz, T., \& Forman, F. (2018). Top down/bottom up: The political and architectural practice of Estudio Teddy Cruz + Fonna Forman. Berlin: Hatje Cantz Verlag $\mathrm{GmbH}$ and Company KG.

Cuff, D., Loukaitou-Sideris, A., Presner, T., Zubiaurre, M., \& Crisman, J. J. (2020). Urban humanities: New practices for reimagining the city. Cambridge, MA: MIT Press.

Dooling, S. (2009). Ecological gentrification: A research agenda exploring justice in the city. International Journal of Urban and Regional Research, 33(3), 621-639.

Escobar, A. (2017). Designs for the pluriverse: Radical independence, autonomy, and the making of worlds. Durham, NC: Duke University Press.

Faste, T., \& Faste, H. (2012). Demystifying "design research": Design is not research, research is design. Paper presented at the IDSA Education Symposium, Boston, MA.

Fleming, B. (2019). Design and the Green New Deal. Places. Retrieved from https://placesjournal.org/ article/design-and-the-green-new-deal

Francis, M. (2005). Community design (re)examined. In J. Hou \& M. Francis (Eds.), (Re)constructing communities: Design participation in the face of change (pp. 18-24). Stanford, CA: Center for Design Research.

Fry, T. (2015). City futures in the age of a changing climate. New York, NY: Routledge.

Ghosn, R., \& Jazairy, E. H. (2020). Geostories: Another architecture for the environment. New York, NY: Actar Publishing.

Goh, K. (2020). Planning the Green New Deal: Climate justice and the politics of sites and scales. Journal of the American Planning Association, 0(0), 1-8.

Hall, P. (2014). Cities of tomorrow: An intellectual history of urban planning and design since 1880 (4th ed.). Malden, MA: Blackwell Publishing Ltd.

Healey, P. (1997). Collaborative planning: Shaping places in fragmented societies. Vancouver: UBC Press.

Henneberger, J. (2019, June 7). RAPIDO is now a proven solution for disaster home rebuilding that is rapid, efficient, and just: Let's use it. Texas Housers. Retrieved from https://texashousers.org/ 2019/06/07/there-is-now-a-proven-solution-fordisaster-home-rebuilding-that-is-rapid-efficient-andjust-lets-use-it

Hou, J. (2018). Public space activism and the space for new commons: Directions for socially engaged design, planning, and placemaking. Arq.Urb, 23, 6-17.

Hou, J., Francis, M., \& Brightbill, N. (2005). (Re)constructing communities: Design participation in the face of change. Davis, CA: Center for Design Research.

Jacobs, J. (1961). Death and life of great American cities. New York, NY: Random House.

Lee, B., Jr. (2020, June 3). America's cities were designed to oppress. Citylab. Retrieved from https://www.bloomberg.com/news/articles/202006-03/how-to-design-justice-into-america-s-cities? utm_medium=website\&utm_source=archdaily.com

MacLaggan, C. (2013, July 14). Hidalgo County fights to ensure census counts everyone. The Texas Tribune. Retrieved from http://www.texastribune.org/ 2013/09/06/hidalgo-countys-fight-ensure-censuscounts-everyon

Manzini, E. (2015). Design, when everybody designs: An introduction to design for social innovation. Cambridge, MA: MIT Press.

Marcuse, P. (2016). Three historic currents of city planning. In S. S. Fainstein \& J. DeFilippis (Eds.), Readings in planning theory, (4th ed., pp. 117-131). Malden, MA: John Wiley \& Sons.

Martin, R. (2020). Abolish oil: From Green New Deal to green reconstruction. Places Journal. Retrieved from https://placesjournal.org/article/abolish-oil

Mattern, S. (2018). Maintenance and care. Places Journal. Retrieved from https://placesjournal.org/ article/maintenance-and-care

Mau, B., Leonard, J., \& Institute Without Boundaries. (2004). Massive change. New York, NY: Phaidon Press Limited.

Moore, J. G. (2015). On humility and loving our cities. Creative Mornings. Retrieved from https:// creativemornings.com/talks/justin-garrett-moore

Pedersen, M. (2020). Bryan C. Lee on design justice and architecture's role in systemic racism. ArchDaily. Retrieved from https://www.archdaily.com/942250/ bryan-c-lee-on-design-justice-and-architecturesrole-in-systemic-racism

Quastel, N. (2009). Political ecologies of gentrification. Urban Geography, 30(7), 694-725.

Recognizing the Duty of the Federal Government to Create a Green New Deal, H. Res. 109 (2019).

Rigolon, A., \& Németh, J. (2019). Green gentrification or 'just green enough': Do park location, size and function affect whether a place gentrifies or not? Urban Studies, 57(2), 402-420.

Rivera, D. Z. (2020). The community union model of organizing in Rio Grande Valley colonias. EPC: Politics and Space. Advance online publication.

Rivera, D. Z., Jenkins, B., \& Randolph, R. (2019). Fighting FEMA: Urban informality and disaster response in Rio Grande Valley colonias. Cambridge, MA: Lincoln Institute of Land Policy. 
Sandercock, L., \& Attili, G. (2014). Changing the lens: Film as action research and therapeutic planning practice. Journal of Planning Education and Research, 34(1), 19-29.

Sbicca, J. (2019). Urban agriculture, revalorization, and green gentrification in Denver, Colorado. Research in Political Sociology, 26, 149-170.

Shi, L. (2020). Beyond flood risk reduction: How can green infrastructure advance both social justice and regional impact? Socio-Ecological Practice Research, 2, 311-320.

Sitte, C. (1889). City planning according to artistic principles. London: Phaidon Press.

Slater, T. (2009). Missing Marcuse: On gentrification and displacement. City, 13(2/3), 292-311.

Sorkin, M. (2001). Some assembly required. Minneapolis, MN: University of Minnesota Press.

Steiner, F. (2014). Frontiers in urban ecological design and planning research. Landscape and Urban Planning, 125, 304-311.

Steiner, F., Simmons, M., Gallagher, M., Ranganathan, J.,
\& Robertson, C. (2013). The ecological imperative for environmental design and planning. Frontiers in Ecology and the Environment, 11(7), 355-361.

Van Assche, K., Beaunen, R., Duineveld, M., \& De Jong, H. (2012). Co-evolutions of planning and design: Risks and benefits of design perspectives in planning systems. Planning Theory, 12(2), 177-198.

Vial, S. (2019). Being and the screen: How the digital changes perception. Cambridge, MA: MIT Press.

Von Hoffman, A. (2008). The lost history of urban renewal. Journal of Urbanism, 1(3), 281-301.

Ward, P. M. (1999). Colonias and public policy in Texas and Mexico: Urbanization by stealth. Austin, TX: University of Texas Press.

Wilson, B. B. (2018). Resilience for all: Striving for equity through community-driven design. Washington, DC: Island Press.

Withers, C. W. J. (2009). Place and the "spatial turn" in geography and in history. Journal of the History of Ideas, 70(4), 637-658.

\section{About the Author}

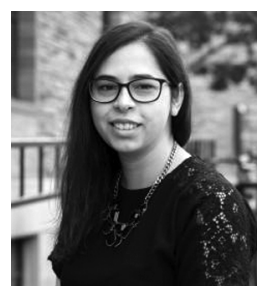

Danielle Zoe Rivera is an Assistant Professor of Environmental Design at the University of Colorado Boulder. Her research examines environmental justice and climate justice in urban design and planning. Rivera holds a PhD in Urban Planning from the University of Michigan, a Master of Architecture from the University of Pennsylvania, and a Bachelor of Architecture from The Pennsylvania State University. 